Discussion Paper No. 624

\title{
AN ASSESSMENT OF CONSUMPTION AND INCOME TAXES IN JAPAN
}

\author{
Charles Yuji Horioka \\ and \\ Shizuka Sekita
}

November 2004

The Institute of Social and Economic Research

Osaka University

6-1 Mihogaoka, Ibaraki, Osaka 567-0047, Japan 


\title{
An Assessment of Consumption and Income Taxes in Japan*
}

\author{
Charles Yuji Horioka** \\ Institute of Social and Economic Research, Osaka University \\ Shizuka Sekita \\ Graduate School of Economics, Osaka University
}

November 22, 2004

\begin{abstract}
In this paper, we conduct a theoretical analysis of the consumption and income taxes from the viewpoints of efficiency and equity, we evaluate the past and present structure of Japan's consumption and income taxes, we consider the role of the consumption tax in stimulating the economy, in reforming the public pension system, and in achieving fiscal reconstruction, and finally, we make policy recommendations based on our findings. We find that the structure of Japan's current consumption and income taxes is problematic from the viewpoints of both efficiency and equity and make policy recommendations that will simultaneously improve both the efficiency and equity of Japan's tax system.
\end{abstract}

Key words: Consumption tax, Corlett and Hague, economic stimulus, efficiency, equity, excess burden, fiscal reconstruction, income tax, inverse elasticity rule, Japan, Japanese economy, optimal taxation, pension reform, Ramsey, and tax reform

Journal of Economic Literature classification numbers: H21 (Efficiency/Optimal Taxation), H23 (Externalities/Redistributive Effects/Environmental Taxes and Subsidies), H24 (Personal Income and Other Nonbusiness Taxes and Subsidies).

**Address for correspondence: Institute of Social and Economic Research, Osaka University, 6-1, Mihogaoka, Ibaraki, Osaka 567-0047, JAPAN. Telephone: (81) 6-6879-8586 or 8574. Facsimile: (81) 6-6878-2766. Email: horioka@iser.osaka-u.ac.jp 


\section{Introduction}

Recently, the consumption tax has attracted widespread interest in Japan because of its potential role in stimulating the economy, in improving the finances of the public pension system, and in achieving fiscal reconstruction. For example, many economists have suggested reducing, then gradually raising, the consumption tax as a way of stimulating the economy and generating inflationary expectations, both the ruling Liberal Democratic Party and the number one opposition party (the Democratic Party of Japan) have proposed using the consumption tax to improve the finances of the public pension system, and the government is proposing a sharp increase in the consumption tax as a way of achieving fiscal reconstruction.

In this paper, we conduct a theoretical analysis of the consumption and income taxes from the viewpoints of efficiency and equity, we evaluate the past and present structure of Japan's consumption and income taxes, we consider the role of the consumption tax in stimulating the economy, in reforming the public pension system, and in achieving fiscal reconstruction, and finally, we make policy recommendations based on our findings. We find that the structure of Japan's current consumption and income taxes is problematic from the viewpoints of both efficiency and equity and make policy recommendations that will simultaneously improve both the efficiency and equity of Japan's tax system.

The structure of the paper is as follows: In section 2 , we conduct a theoretical analysis of the consumption and income taxes from the viewpoint of efficiency and equity; in section 3 , we evaluate the past and present structure of Japan's consumption and income taxes; in sections 4,5 , and 6 , we consider the role of the consumption tax in stimulating the economy, in reforming the public pension system, and in achieving fiscal 
reconstruction, respectively; and finally, in section 7 , we make policy recommendations based on our findings.

\section{A Theoretical Analysis of the Consumption and Income Taxes}

In this section, we conduct a theoretical analysis of the consumption and income taxes. When evaluating a tax, there are two criteria that are commonly used-efficiency and equity. Efficiency refers to whether a tax distorts the decisionmaking process of economic agents (i.e., whether it causes an excess burden), and equity refers to whether a tax has favorable or unfavorable distributional consequences. In this section, we evaluate the consumption and income taxes from the viewpoints of both efficiency and equity.

\subsection{Efficiency}

First, we analyze the consumption and income taxes from the viewpoint of efficiency.

\subsubsection{The Consumption Tax}

The consumption tax introduces at least two distortions: it distorts the allocation of consumption among different consumption goods (excluding leisure), and it distorts the allocation of consumption between leisure and other consumption goods.

Looking first at the distortion in the allocation of consumption among different consumption goods (excluding leisure), the consumption tax distorts this allocation decision by raising the prices of some or all consumption goods. A comprehensive consumption tax raises the prices of all consumption goods (excluding leisure) by the 
same percentage, but this does not necessarily mean that such a tax does not cause any distortions. The reason is that different consumption goods have different compensated price elasticities of demand. Even if the prices of all goods are increased by the same percentage, goods whose compensated price elasticity of demand is relatively high (in absolute value) will show a more pronounced decline in demand than goods whose compensated price elasticity of demand is relatively low (in absolute value).

Ramsey (1927) first pointed out this problem and proposed the "inverse elasticity rule" or "Ramsey rule" as a way of eliminating the distortion in the allocation of consumption among different consumption goods caused by the imposition of a consumption tax. This rule states that the tax rate of each good should be inversely proportional to the absolute value of the compensated price elasticity of demand of that good. As pointed out by Hatta (2004a, 2004b), this rule is not very useful in actual practice because it suffers from an important defect: it makes the unrealistic assumption that all cross-price elasticities of demand are zero and that even goods with a high compensated price elasticity of demand (in absolute value) have no substitutes. Moreover, since necessities often have low compensated price elasticities of demand, applying Ramsey's (1927) inverse elasticity rule will require us to impose higher tax rates on necessities, making the tax regressive. Thus, implementing the inverse elasticity rule may or may not improve efficiency, and moreover, it will have an adverse impact on equity.

Looking next at the distortion in the allocation of consumption between leisure and other consumption goods, it is almost impossible to accurately measure the leisure consumption of each individual (i.e., the number of hours each individual devotes to 
leisure), and thus it is not feasible to impose a tax on leisure. And if all consumption goods other than leisure are taxed while leisure is not, this will lead to a distortion in the allocation of consumption between leisure and other consumption goods, with leisure being overconsumed and all other consumption goods being underconsumed.

Corlett and Hague (1953) pointed out that this distortion can be alleviated by taxing complements of leisure (such as summer homes, yachts, golfing goods, movie tickets, etc.) more heavily and substitutes of leisure (such as washing machines, vacuum cleaners, electric ranges, etc.) more lightly than other consumption goods.

\subsubsection{Income Tax}

The income tax introduces at least two distortions. The first distortion caused by the income tax is that, by taxing labor income, it discourages labor, or to put it another way, it subsidizes leisure, as in the case of the consumption tax. Thus, it leads to an undersupply of labor and to an overconsumption of leisure. The solution is to make labor income tax-exempt.

The second distortion caused by the income tax is that, by taxing capital income (interest, dividends, rent, etc.), it discourages saving. The solution is to make capital income tax-exempt.

However, if both labor income and capital income are made tax-exempt, the government will not be able to raise any tax revenue. Thus, the government needs to impose taxes on either labor income and/or capital income. It can be shown that it is optimal to tax labor income if labor supply has the lower compensated price elasticity and to tax capital income if saving has the lower compensated price elasticity. It is believed that labor supply has a lower compensated price elasticity than saving, and if 
that is the case, it is optimal to make capital income tax-exempt and to tax only labor income (i.e., to impose a wage tax).

\subsubsection{Conclusion}

As we have seen, both the consumption and income taxes cause distortions in consumer behavior. The only tax that does not cause any distortions is the poll or lumpsum tax, which collects the same amount of tax from each individual, or if individuals are heterogenous, a poll or lumpsum tax that collects the same amount of tax from all individuals of each type, but poll taxes are unrealistic, not to mention regressive. Thus, the only choice is to impose a tax that causes one kind of distortion or another.

As Hatta (2004a, 2004b) notes, it is often the case that, by mitigating one distortion, one exacerbates a different distortion. For example, raising the tax rate on complements of leisure and lowering the tax rate on substitutes for leisure will mitigate the distortion in the allocation of consumption between leisure and other consumption goods, but at the same time, it will exacerbate the distortion in the allocation of consumption among different consumption goods (excluding leisure). Thus, there is a trade-off between these two kinds of distortions.

An optimal tax structure is one that takes account of this trade-off and maximizes social welfare. According to Hatta (2004a, 2004b), an optimal tax structure is one in which a higher tax rate is imposed on strong complements of leisure, a lower tax rate is imposed on strong substitutes for leisure, and a uniform tax rate is imposed on all other goods (goods with a low cross-price elasticity of demand with leisure). In other words, he finds that it is optimal to use consumption taxes to alleviate the 
distortion in the allocation of consumption between leisure and other consumption goods.

\subsection{Equity}

In this section, we analyze the consumption and income taxes from the viewpoint of equity.

\subsubsection{Consumption Tax}

Since the propensity to consume generally decreases with income, a sales tax that is imposed at the time of sale will be regressive and hence inequitable. The solution is to impose an expenditure tax instead of a sales tax. An expenditure tax is a tax in which individuals file a tax return and pay a tax on the difference between their income and their saving (where saving is calculated as the net increase in their assets). The two taxes are similar in the sense that they are both imposed on consumption but they are different in the sense that a sales tax cannot be made progressive while an expenditure tax can be made as progressive as one wants. The problem is that an expenditure tax is difficult to implement and has never been tried in actual practice in any country.

Given that an expenditure tax is not practical, the second-best solution is to impose a sales tax but to impose a lower or zero tax rate on food and other necessities and to impose a higher tax rate on luxury goods. There are many examples both in Japan and in other countries of certain goods being exempted entirely from consumption taxes or of differential tax rates being imposed on different commodity groups. For example, in the United States, there is no national consumption tax, but 
most states have a state sales tax, and in about half of the states that have a sales tax, food is tax-exempt, and in most states that have a sales tax, prescription drugs are tax-exempt. As another example, in many European countries, the consumption (value added) tax has two or three tiers, with a lower tax rate being levied on food. As a final example, Japan imposed a commodity tax on certain consumption goods (primarily luxury goods) until the general consumption tax was introduced on April 1, 1989. Thus, many countries including Japan have made efforts to alleviate the regressivity of the consumption tax.

\subsubsection{Income Tax}

The income tax can be made as progressive as one wants, and thus it is easy to achieve equity using the income tax.

\subsubsection{Conclusion}

Unless the consumption tax takes the form of an expenditure tax, which is not practical, it is difficult to achieve full equity using the consumption tax, and thus it is easier to achieve full equity using the income tax.

\subsection{Consumption Tax or Income Tax?}

In order for the government to function, it needs tax revenue, and thus the government needs to impose one kind of tax or another. The trick is to find a tax system that simultaneously achieves efficiency and equity. The problem is that, although it is sometimes possible to achieve efficiency and equity simultaneously, the two objectives are often contradictory. 
For example, in the case of the consumption tax, since the compensated price elasticity of demand is often low (in absolute value) in the case of necessities, if we apply Ramsey's (1927) inverse elasticity rule, we would have to set a higher tax rate for necessities than for other goods, and thus we would have to sacrifice equity for efficiency. By contrast, since Corlett and Hague's (1953) rule entails imposing a higher tax rate on complements of leisure and since many complements of leisure are luxury goods, we can achieve both efficiency and equity simultaneously by implementing Corlett and Hague's rule.

In the case of the income tax, it is optimal from the viewpoint of efficiency to tax labor income more heavily than capital income (assuming that labor supply is more price-inelastic than saving), but in general, the share of capital income in total income rises with income, and thus from the viewpoint of equity, it is optimal to tax capital income more heavily than labor income. Thus, the two objectives conflict in this case.

Hatta (2004a, 2004b) argues that we should not attempt to achieve equity through the consumption tax because there are other taxes (such as the progressive income tax, the land tax, the inheritance tax, etc.) that are better suited to attaining equity. Hatta (2004, 2004b) asserts that we should leave the attainment of equity to these taxes and that we should use the consumption tax to alleviate the distortion in the allocation of consumption between leisure and other consumption goods by applying Corlett and Hague's (1953) rule, but as argued earlier, we can achieve both efficiency and equity simultaneously by applying Corlett and Hague's rule.

\section{An Evaluation of Japan's Tax System}

In this section, we evaluate the past and present structure of Japan's 
consumption and income taxes from the viewpoints of both efficiency and equity.

\subsection{Consumption Tax}

First, we evaluate the past and present structure of Japan's consumption tax.

\subsubsection{Efficiency}

Until March 31, 1989, Japan did not have a general consumption tax but commodity taxes ranging from five to 30 percent were imposed on certain goods (mostly luxury goods). If we look at the structure of the commodity taxes, food and other goods with a low compensated price elasticity of demand (in absolute value) were tax-exempt, meaning that Ramsey's (1927) inverse elasticity rule was not being followed and that the opposite was being done. Looking next at whether the structure of the commodity taxes was consistent with Corlett and Hague's (1953) rule, many of the goods upon which commodity taxes were imposed are clearly close complements of leisure (such as golfing goods, billiard goods, motor boats, water game supplies, hand gliders, musical instruments, televisions, stereos, etc.), and some of them are close substitutes for leisure (such electric vacuum cleaners, electric washing machines, etc.) so it is not clear whether or not the structure of the commodity taxes was consistent with Corlett and Hague's (1953) rule. However, it is probably the case that commodity taxes were imposed more frequently on complements of leisure than on substitutes for leisure, meaning that they alleviated the distortion in the allocation of consumption between leisure and other consumption goods to some extent, thereby improving efficiency.

The Japanese government abolished the commodity taxes on selected goods and introduced a 3\% general consumption tax on April 1, 1989, and raised the general 
consumption tax from $3 \%$ to $5 \%$ on April 1, 1997. This general consumption tax is uniform, and thus it does not reflect either Ramsey's (1927) inverse elasticity rule or Corlett and Hague's (1953) rule. Thus, it distorts both the allocation of consumption among different consumption goods (excluding leisure) as well as the allocation of consumption between leisure and other consumption goods and is not an efficient tax by any means. However, unlike the earlier commodity taxes, food and other necessities with a relatively low compensated price elasticity of demand (in absolute value) are no longer tax-exempt, and thus the current general consumption tax is closer to Ramsey's (1927) inverse elasticity rule than the earlier commodity taxes. However, whereas the earlier commodity taxes adhered to Corlett and Hague's (1953) rule to some extent, the current general consumption tax does not adhere to this rule at all.

Thus, by moving from the earlier commodity taxes to the current general consumption tax, the distortion in the allocation of consumption among different consumption goods (excluding leisure) was alleviated but the distortion in the allocation of consumption between leisure and other consumption goods, a more serious problem, was exacerbated. Thus, there is a high probability that the overall efficiency of the consumption tax declined due to the transition from commodity taxes to a general consumption tax.

\subsubsection{Equity}

In the case of the commodity taxes that were in effect until March 31, 1989, food and other necessities were tax-exempt and a high tax rate was imposed on many luxury goods. Thus, the earlier commodity taxes achieved equity to a considerable extent. 
However, the general consumption tax that was introduced on April 1, 1989, is a sales tax rather than an expenditure tax, and moreover, the tax rate on food and other necessities is not relatively low or zero and the tax rate on luxury goods is not relatively high. Thus, it can be said to be a regressive and thus inequitable tax.

\subsubsection{Conclusion}

As we have argued, the transition from commodity taxes to a general consumption tax probably reduced the efficiency of the consumption tax and clearly reduced the equity thereof. Thus, from the viewpoint of optimal taxation, one cannot say that it was a desirable tax reform.

\subsection{Income Tax}

Next, we evaluate the past and present structure of Japan's income tax.

\subsubsection{Efficiency}

In the past, the Japanese tax code included many tax breaks for saving (capital income) such as the maruyuu system (the tax-free system for small deposits), and as a result, the tax rate on capital income was probably lower than the tax rate on labor income. Thus, (assuming that labor supply is more price-inelastic than saving) the structure of Japan's income tax scored high with respect to efficiency.

However, the maruyuu system was restricted primarily to those aged 65 or older on March 31, 1988, and it is scheduled to be abolished totally (in principle) on December 31, 2006, and other tax breaks on saving (capital income) have also been abolished. This has reduced the efficiency of the income tax and will cause it to decline 
even further in the future.

Turning to a separate issue, the progressivity of Japan's income tax has declined over time, as discussed in section 3.2.2. below, and this will improve efficiency to the extent that it alleviates the disincentive effects on the labor supply of high-income individuals. However, since labor supply is believed to be relatively inelastic, the efficiency gains from reduced progressivity are presumably relatively small.

\subsubsection{Equity}

Japan's income tax is non-linear and progressive, but the degree of non-linearity and progressivity has declined over time. Table 1 shows how the number of brackets and the range of tax rates have fluctuated over time, and as this table shows, the degree of non-linearity and progressivity and hence the equity of Japan's income tax has declined since the 1980s.

Table 1: Trends in the Number of Brackets and in the Range of Tax Rates of the National Income Tax in Japan

1971 83: 19 brackets $(10 \sim 75 \%)$

1984 86: 15 brackets $(10.5 \sim 70 \%)$

1987: 12 brackets $(10.5 \sim 60 \%)$

1988: 6 brackets $(10 \sim 60 \%)$

1989 98: 5 brackets $(10 \sim 50 \%)$

1999 present: 4 brackets $(10 \sim 37 \%)$ 
Next, we would like to confirm these trends from another perspective. Tables 2 and 3 show the share of taxpayers for whom each marginal tax rate applied in 1988 and 2001, and as can be seen from these tables, the 1999 income tax reform caused the share of taxpayers for whom the $10 \%$ marginal tax rate applies to increase sharply from $60.8 \%$ to $69.2 \%$ and caused the share of taxpayers for whom the $20 \%$ marginal tax rate applies to decrease sharply from $28.4 \%$ to $22.0 \%$, as a result of which the lowest marginal tax rate applied to a full $70 \%$ of taxpayers. This corroborates the trend toward a less non-linear, less progressive, and less equitable income tax.

Table 2: The Share of Taxpayers for Whom Each Marginal Tax Rate Applies (1998)

\begin{tabular}{cc} 
Marginal Tax Rate & Share of Taxpayers \\
\hline $10 \%$ & $60.8 \%$ \\
$20 \%$ & $28.4 \%$ \\
$30 \%$ & $6.5 \%$ \\
$40 \%$ & $2.3 \%$ \\
$50 \%$ & $2.0 \%$
\end{tabular}

Source: Kokuzei-chou Toukei Nenpou-sho (The Statistical Yearbook of the National Tax Agency), 1998 edition

Table 3: The Share of Taxpayers for Whom Each Marginal Tax Rate Applies (2001)

\begin{tabular}{cc}
\hline Marginal Tax Rate & Share of Taxpayers \\
\hline $10 \%$ & $69.2 \%$ \\
$20 \%$ & $22.0 \%$
\end{tabular}


Source: Kokuzei-chou Toukei Nenpou-sho (The Statistical Yearbook of the National Tax Agency), 2001 edition

\subsubsection{Conclusion}

Assuming that labor supply is more price-inelastic than saving, the gradual abolition of various tax breaks for saving (capital income) has lowered the efficiency of Japan's income tax, and the reduction in progressivity has reduced the equity thereof. Thus, Japan's recent income tax reforms have reduced the efficiency as well as the equity of the income tax, and thus one cannot say that they were desirable from an optimal taxation standpoint.

\section{The Role of the Consumption Tax in Stimulating the Economy}

The Japanese economy is finally recovering from more than a decade of recession and price deflation, and during the recession, many economists advocated using the consumption tax as a tool for stimulating the economy and ending price deflation. In this section, we explain how one could stimulate the economy using the consumption tax and the merits of doing so.

On January 18, 2002, one of the co-authors of this paper wrote an opinion piece in Nihon Keizai Shinbun in which he proposes lowering or abolishing the general consumption tax for a fixed period of time and then raising it gradually (see Horioka (2002) for details).

Such a policy would have at least four advantages: 
First, it would be effective. By lowering or abolishing the general consumption tax for a fixed period of time and then raising it gradually would stimulate consumption and hence the economy as a whole because consumers would accelerate purchases of consumption goods, especially non-perishable goods, in order to take advantage of temporarily lower consumption taxes.

Second, it would not cost the government very much in foregone tax revenue. If the permanent income hypothesis applies, a temporary income tax cut would not have much impact on consumption because it would not have much impact on permanent income. In order to be effective in stimulating consumption, the income tax cut would have to be permanent so that it increases permanent income, but a permanent income tax cut would lead to a massive loss of tax revenue. By contrast, a consumption tax cut would be more effective if it were temporary because only a temporary consumption tax cut would induce consumer to accelerate their purchases of consumption goods. Thus, a temporary consumption tax cut would be preferable to a permanent consumption tax cut for two reasons-first, because it would be more effective, and second, because it would not cost the government nearly as much in foregone tax revenue.

Third, it would be effective as a means of ending price deflation. Lowering or abolishing the general consumption tax for a fixed period of time and then raising it gradually would generate inflation, and if the inflation that is generated causes inflationary expectations to take root, inflation will continue even after the gradual increases in the consumption tax rate end. Thus, if all goes well, the same fiscal policy would simultaneously stimulate consumption and end price deflation.

Fourth, it would be equitable. Since the propensity to consume generally declines with income, low-income consumers will receive a disproportionate share of the 
benefits of the temporary consumption tax reduction or abolition. Thus, the temporary consumption tax reduction or abolition would have the added benefit of increasing equity.

Thus, a policy of temporarily reducing or abolishing the consumption tax would confer at least four advantages and does not have any major disadvantages.

The Japanese government relied on temporary income tax cuts to stimulate consumption and hence the economy as a whole during the decade-long recession, but as noted earlier, theory predicts that income tax cuts will not be effective unless they are permanent but permanent income tax cuts would have been too costly to the government in terms of foregone tax revenues. Thus, the Japanese government would have been better off temporarily reducing or abolishing the consumption tax instead of lowering income taxes as a way of stimulating the economy.

The Japanese economy is finally recovering, but the recovery is showing signs of slowing down, and if the Japanese economy should slide back into recession, the Japanese government should consider using a temporary reduction or abolition of the consumption tax as a way of stimulating the economy.

\section{Pension Reform and the Consumption Tax}

Japan's public pension system is, in effect, a pay-as-you-go system, meaning that the pension benefits of retirees are financed by the pension contributions of current workers. Thus, the finances of the public pension system will depend heavily on the age structure of the population, and the finances of Japan's public pension system are deteriorating rapidly due to the rapid aging of her population. The Japanese government has tried to improve the finances of the public pension system by reducing 
benefits, raising contributions, and raising the age at which pensions are paid, but even these reforms have proven to be inadequate. As a result, many have proposed raising the consumption tax and using the additional revenue to bolster the finances of the public pension system. In this section, we discuss the merits and demerits of using consumption tax revenue to bolster the finances of the public pension system.

Both the ruling Liberal Democratic Party and the number one opposition party (the Democratic Party of Japan) have proposed raising the consumption tax and using the additional revenue to bolster the finances of the public pension system, but their proposals differ greatly. We now discuss the two parties' proposals in turn.

\subsection{The Liberal Democratic Party proposal}

As part of the 2000 reform of the public pension system. it was decided that the subsidy from general revenues to the basic pension (a fixed-sum public pension for which everyone is eligible) would be increased from one-third to one-half, but it was not specified how this increase in the subsidy from general revenue would be financed. The most likely financing method is to increase the consumption tax, and the Tax Deliberative Council has recommended increasing the consumption tax after "clarifying the connection between the higher consumption tax and social security-related expenditures.” However, Prime Minister Junichiro Koizumi has pledged not to raise the consumption tax during his tenure, so any hike in the consumption tax will have to wait until after his term ends.

\subsection{The Democratic Party of Japan proposal}

The Democratic Party of Japan proposes creating a two-tiered public pension 
system for which everyone is eligible. The first tier (the National Basic Pension (Kokumin Kiso Nenkin)) would be financed by a Pension Earmarked Consumption Tax (Nenkin Mokuteki Shouhi-zel), a 3\% consumption tax that would be levied on top of the current 5\% tax. The second tier (the Earnings-related Pension (Shotoku Hirei Nenkin)) would be financed by the pension contributions of current workers and would be proportional to the beneficiary's past earnings. Two unique features of the Democratic Party of Japan's proposal are (1) that the $3 \%$ increment to the consumption tax would be used exclusively to finance the National Basic Pension and (2) that the amount of the National Basic Pension would not be fixed for everyone but would be higher for those with a lower Earnings-related Pension. In other words, even though the $3 \%$ consumption tax that would be used to finance the National Basic Pension is regressive, the amount of this pension is higher for the low-income and thus the regressivity of the way in which this pension is financed would be largely offset by the redistributive benefit structure.

\subsection{Conclusion}

Thus, both the Liberal Democratic Party and the Democratic Party of Japan propose relying on the consumption tax to finance the basic pension (the National Basic Pension in the case of the Democratic Party of Japan proposal), but we are against the idea of using a regressive tax such as the consumption tax to finance the basic pension. However, the Democratic Party of Japan proposes paying a larger National Basic Pension to low-income individuals, and doing so would cause the regressivity of the way in which this pension is financed to be largely offset by the redistributive benefit structure. Thus, we feel that the proposal of the Democratic Party of Japan is far 
preferable to the proposal of the Liberal Democratic Party.

We would actually prefer switching from a pay-as-you-go public pension to a fully funded system that pays actuarially fair benefits and financing the unfunded liabilities of the public pension system via the issuance of long-term government bonds that would be retired gradually so that the burden of these unfunded liabilities would be spread out over a number of generations (see Horioka (2001) for details)). However, if implementing this proposal is not politically feasible, we favor the Democratic Party of Japan's proposal as a second-best solution.

\section{Fiscal Reconstruction and the Consumption Tax}

The Japanese government's outstanding debt as a ratio of GDP is by far the highest among the major industrialized nations, due in large part to the repeated economic stimulus packages implemented during the decade-long recession, and thus fiscal reconstruction is an urgent priority of the Japanese government. The Japanese government plans to rely primarily on hikes in the consumption tax to achieve fiscal reconstruction, and its calculations suggest that the consumption tax would have to be raised from the current $5 \%$ to $21 \%$ during the next ten years.

However, we are strongly against the use of hikes in the consumption tax to achieve fiscal reconstruction, at least if the current highly regressive structure of the consumption tax is not changed. Unless the consumption tax can be converted to an expenditure tax, which can be made as progressive as one wants, or the tax rate on food and other necessities is set at a low or zero rate, we favor relying instead on increasing income tax revenue by stricter enforcement and/or greater progressivity. In Japan, there is widespread evasion of income taxes by the self-employed, farmers, etc., (even 
though salaried workers are unable to evade income taxes because such taxes are automatically deducted from their paychecks), and thus, revenue from the income tax could be increased considerably even without changing tax rates if enforcement were made stricter (for example, by introducing a taxpayer identification number system, increasing the number of tax officials, and/or increasing the proportion of tax returns that are audited). Moreover, stricter enforcement of the income tax would simultaneously enhance the inter-occupational equity thereof, thereby killing two birds with one stone. If stricter enforcement of the income tax does not increase tax revenue by a sufficient amount, we favor increasing tax revenue by increasing the progressivity of the income tax. Since the burden of income taxes in Japan is far lower than in other countries, there is considerable scope for generating more revenue from the income tax by increasing its progressivity. We favor achieving fiscal reconstruction by raising revenue from the income tax rather than by raising revenue from the consumption tax primarily because of equity considerations. The income tax is far more progressive (and hence more equitable) than the consumption tax to begin with, and moreover, if we increase the amount of revenue generated by the income tax by increasing its progressivity, the income tax will be made even more equitable at the same time that tax revenue is increased, thereby killing two birds with one stone.

\section{Policy Recommendations}

In the foregoing sections, we conducted a theoretical analysis of the consumption and income taxes from the viewpoints of efficiency and equity, evaluated the past and present structure of Japan's consumption and income taxes, and considered the role of the consumption tax in stimulating the economy, in reforming the public pension system, 
and in achieving fiscal reconstruction. In this section, we make some policy recommendations based on the findings of the foregoing sections.

Regarding the structure of the consumption tax,

(1) We recommend implementing Corlett and Hague's (1953) rule by raising the tax rate of the consumption tax on complements of leisure and lowering the tax rate on substitutes for leisure.

(2) We recommend enhancing the equity of the consumption tax by lowering the tax rate on food and other necessities to a low or zero rate.

Recommendation (1) would enhance both the efficiency and equity of the consumption tax, assuming that complements of leisure tend to be luxury goods, while recommendation (2) would enhance the equity of the consumption tax but would have an adverse impact on its efficiency.

Regarding the structure of the income tax,

(3) We recommend alleviating the disincentive effects of the income tax on saving by re-introducing tax breaks on saving (capital income).

(4) We recommend enhancing the equity of the income tax by increasing its progressivity.

Recommendation (3) would enhance the efficiency of the income tax but would, at the same time, have an adverse impact on equity (assuming that the share of capital income in total income increases with income), but recommendation (4) would enhance the equity of the income tax, thereby offsetting the adverse effect of recommendation (3) on the equity of the income tax. Recommendation (4) would, at the same time, have an adverse impact on efficiency to the extent that it discourages the labor supply of high-income individuals, but this effect would presumably be small since labor supply is 
believed to be relatively inelastic.

Regarding the three current policy issues discussed above,

(5) We recommend temporarily lowering or abolishing the consumption tax, then gradually increasing it, if the economy should fall back into recession and price deflation because such a policy would simultaneously stimulate demand and create price inflation.

(6) We recommend moving from a pay-as-you-go public pension system to a fully funded system, but assuming that this is not politically feasible, we support the Democratic Party of Japan's pension reform proposal.

(7) We recommend achieving fiscal reconstruction not by raising the consumption tax but by stricter enforcement and greater progressivity of the income tax.

Regarding recommendation (7), the Japanese government seems intent on achieving fiscal reconstruction primarily by raising the consumption tax and has calculated that the consumption tax would have to be raised to $21 \%$ by 2014 in order to achieve fiscal reconstruction. We are strongly opposed to this proposal because of the regressivity of the consumption tax, but if there is no way to avoid implementing the government's proposal, we feel that it is all the more necessary to enhance the efficiency and equity of the consumption tax by implementing recommendations (1) and (2). Regarding recommendation (2), it is indeed fortunate that the Japanese government's Tax Deliberation Council has indicated its willingness to consider introducing a lower tax rate on food when the consumption tax is increased despite possible implementational difficulties if there is sufficient public support for such a proposal.

We are confident that, if our policy recommendations are implemented, they 
will make Japan's tax system more efficient as well as equitable and that they will revitalize Japan's economy.

\section{Acknowledgements}

We are grateful to Miyohei Shinohara and the other members of the Public Policy Study Group of the Institute for Statistical Research (Toukei Kenkyuu-kai) for their valuable comments, and Horioka is grateful to the Ministry of Education, Culture, Sports, Science and Technology of the Japanese Government for Grant-in-Aid for Scientific Research number 12124207, which supported this research.

\section{References}

Corlett, W. C., and Hague, D. C. (1953), "Complementarity and the Excess Burden of Taxation," Review of Economic Studies, vol. 21, no. 1, pp. 21-30.

Hatta, Tatsuo (2004a), "Zeishuu Seiyaku no Moto de no Buppin-zei Kaikaku (Reform of the Commodity Tax under Revenue Constraint)," in Kikuo Iwata, Yasushi Iwamoto, Yuuzoo Honda, and Akihiko Matsui, eds., Gendai Keizai-gaku no Chooryuu (Trends in Contemporary Economics) (Tokyo: Toyo Keizai Shinposha), pp. 3-27.

Hatta, Tatsuo (2004b), "A Theory of Commodity Tax Reform under Revenue Constraint," Japanese Economic Review, vol. 55, no. 1 (March), pp. 1-16.

Horioka, Charles Yuji (2001), "Japan's Public Pension System in the Twenty-first Century," in Magnus Blomstrom, Byron Gangnes, and Sumner La Croix, eds., Japan's 
New Economy: Continuity and Change in the Twenty-First Century (New York: Oxford University Press Inc.), pp. 99-119.

Horioka, Charles Yuji (2002), "Zeisei de Kojin Shouhi Shigeki: Kai-isogi e to Yuudou, Keiki Kaifuku-go no Zouzei wo Kouyaku (Stimulate Personal Consumption using the Tax System: Encourage the Acceleration of Purchases, Promise a Tax Increase after the Economy Recovers)," Keizai Kyoushitsu (Economic Classroom) section, Nihon Keizai Shinbun (Japan Economic Journal), January 18, p. 29.

Ramsey, F. P. (1927), "A Contribution to the Theory of Taxation,” Economic Journal, vol. 37, no. 1 (March), pp. 47-61. 